\title{
Kazakhstan Realities in the Perception of Representatives of American Ethnolinguoculture
}

Zh.K. Kiynova, $^{+*}$ S.K. Sansyzbayeva, ${ }^{\dagger}$ A.I. Akhmetzhanova, ${ }^{\dagger}$ U.E. Mussabekova, ${ }^{\dagger}$ I.S. Muratbayeva ${ }^{\top}$

\section{Abstract}

The purpose of the article is to describe the axiological characteristics of the realities of modern Kazakhstan society and the ethnic character in the perception of representatives of American ethnolinguoculture by using experimental data. Based on the analysis and description of associates obtained as a result of the associative experiment and sociocultural questionnaire survey, conclusions were drawn about the national-cultural markedness of a linguistic sign. The use of the method of the free-associative test helped to obtain objective and subjective characteristics for each stimulus word. The analysis of associates of American informants determined the novelty of the approach to the problem of intercultural communication in multicultural Kazakhstan society. The generalisation and analysis of associates and answers to questions on the sociocultural topic made it possible to construct a conceptual structure of the image of Kazakhstan and its realities in the consciousness of a linguistic personality of another culture. Also, in the article, an attempt was made to conduct a sociocultural questionnaire survey as an alternative research method. The answers and comments of respondents made it possible to comprehend and describe the respondents' attitudes and opinion on the national-cultural values of the Kazakh people, to determine a range of discussion problems in different worldviews and to counter sociocultural realities in intercultural communication.

Keywords: Intercultural Communication, Associative Experiment, Ethnolinguoculture, Linguistic Consciousness, Ethnodescriptors, Kazakhstan

\footnotetext{
${ }^{\dagger}$ 1Al Farabi Kazakh National University, Almaty, Kazakhstan, al-Farabi ave. 71. Post- 050040

${ }^{*}$ Corresponding Author Email: kiynova@inbox.ru

'Saint-Petersburg University of the Humanities and Social Sciences (Almaty Branch), Almaty, Kazakhstan, Chaikovskiy, 9/11, Post- 050004

(C) 2018 Kiynova et al. This is an Open Access article distributed under the terms of the Creative Commons Attribution License (http://creativecommons.org/licenses/by/2.0), which permits unrestricted use, distribution, and reproduction in any medium, provided the original work is properly cited.
} 


\section{Introduction}

Today, sociolinguistics, psychology, and anthropology attach great importance to intercultural communication. Intercultural communication is the involvement of two or more persons in a cross-cultural meeting (Kim, 2014: 520).

There is a broad understanding of the nature of intercultural communication in the scientific literature. It is, first, the communication of representatives of different ethnic cultures (Drotianko \& Yahodzinskyi, 2016). Due to intercultural communication in the Kazakh society, many people become more sensitive and competent to the national and cultural values of the Kazakh people (Wang \& Zhou, 2016: 5).

Some studies show that cultural differences in the process of intercultural communication have different effects on processes and outcomes, both in business negotiations and in the informal discussion (Akpinar, Alfano \& Kersten, 2017: 140, Drotianko \&Yahodzinskyi, 2016).

The problems of interethnic relations remain relevant in the context of the development of modern Kazakhstan as a multicultural state. A long-term interaction of representatives of different ethnic groups living in Kazakhstan led to the formation of common values and stereotypes. Solving problems in the difference of belief systems can enhance the national and cultural significance of the linguistic sign (Kecskes, 2017: 15-18).

The study of the specifics of the relationship of a particular pair of cultures is of practical significance for intercultural contacts. The interaction and uniqueness of two "distant" and contrasting Kazakh and American ethnolinguocultures are relevant to this study.

The associative experiment with representatives of American ethnolinguoculture was conducted to describe intercultural differences and integrating the data on Kazakhstan realities and the uniqueness of the Kazakh mentality. The results of this experiment are more impressive than those of the experiment with other respondents - representatives of different nationalities (Russians, Koreans, Germans, Uighurs, Ingush and other nationalities) inhabiting multinational Kazakhstan. "The search for the national-cultural specificity of linguistic consciousness indicates the status of linguistic consciousness: it is regarded as a means of understanding another culture in its subject, activity and mental form, as well as a means of understanding one's own culture. The results of large-scale associative experiments help to understand how and what a particular culture imposes forms on the perception of the surrounding reality" (Ufimtseva, 2004: 4).

More than 50 American students who studied at the Kazakh National University named after Al-Farabi in 2014-2015 and 2015-2016 academic years upon the educational programme "Flagship" took part in the experiment. The primary purpose of their stay in Kazakhstan was an extensive study and acquisition of the Russian language and culture, and for this reason, the questionnaire survey was conducted in Russian. The socialisation of a person in a different cultural environment took place in the context of intercultural communication; therefore, it was imperative that the experiment had to be conducted in the last academic week. For the whole academic year, American students assimilated to the Kazakh culture learned more about Kazakhstan and the Kazakhs and living in Kazakh families allowed them to understand the features of the national mentality better, to study the customs and traditions of the Kazakh people. We think that all these circumstances allowed us to obtain objective data, analyse and describe them in this article.

The object of the research is the axiological characteristics of the realities of modern Kazakhstan society and the description of the ethnic character in the perception of American youth based on experimental data. Therefore, we consider values as fundamental characteristics of culture, which is a priority in contemporary studies in cognitive and cultural linguistics (Vezhbitskaya, 2001: 115; Vorkachev, 2002: 93; Kubryakova, 2010: 67).V. We 
proposed a detailed grading of a set of axiological principles. Karasik, who divides values into individual (personal, authorial), micro group (for example, in the family, between close friends), macro group (social, role, status and other values), ethical and universal ones. At the same time, there are values of a particular type of civilisation (for example, the benefits of modern industrial society, the values of medieval Christianity), as well as ethnic and universal values (Karasik, 2002: 167).

American scientists pay particular attention to the study of the system of national-cultural values and beliefs, rightly considering that this is the central ethno-creating principle: "What among all of its regional and cultural diversity gives America its national character and enables its citizens to affirm their common identity as Americans? Having a particular race or creed or lifestyle does not identify one as an American. However, there are certain ideals and values, rooted in the country's history, which many Americans share" (Fiedler, Jansen, \& Norman-Risch, 2004: 167).

The next section describes the methods applied to this research. Following this, it represents the literature review. The results and the discussion section follow this.

\section{Methods}

The primary general scientific methods of observation, comparison, and description aimed at the generalisation of the results obtained, data analysis, interpretation, systematisation and classification have been usedin work. Psycholinguistic methods based on the analysis of verbal associations of respondents are the most informative among the experimental studies aimed at revealing the images of consciousness of representatives of various ethnolinguocultures. The reactions received for a particular stimulus word are caused by the specificity of linguistic knowledge and reflect its national-cultural component. This research is aimed at revealing the axiological characteristics of ethnocultural realities in intercultural communication using associations about Kazakhstan and Kazakhs that are evoked in the linguistic consciousness of American respondents. Therefore, the article analyses and describes the associative field as the final product of the associative experiment. The theoretical bases of the research are the provisions on the image of linguistic consciousness developed by staff members of the Psycholinguistics and Communication Theory Department of the Institute of Linguistics of the Russian Academy of Sciences E.F. Tarasov (2003), N.V. Ufimtseva (2004), and Yu.A. Sorokin (1994). The associative fields formed from verbal reactions are the result of the associative experiment.

In this research, free-associative experiment as a productive psycholinguistic method and a questionnaire survey has been used to reveal figurative and evaluative characteristics formed in American students during their stay in Kazakhstan. During this experiment, the informants responded to the suggested set of stimulus words with any language units denoting images that appear in their minds for a specified period. The psycholinguistic associative experiment was based on the processing of verbal associations of respondents on a stimulus word, a reaction word. Two clusters of lexical units were offered as the experimental material: a) sociopolitical and sociocultural Kazakhstan realities characterising the Republic of Kazakhstan as a sovereign state: Kazakhstan, the Kazakhs, Nazarbayev, Astana, Almaty, the Kazakh language, Kazakh family, Kazakh National University named after Al-Farabi; b) ethnocultural Kazakh realities - lexical units that were one-sidedly lacunised for representatives of American culture: nauryz, beshbarmak, bauyrsaki, kumys, tenge. Based on the analysis of the reactions received for all stimulus words in the questionnaire, a conclusion was drawn about the Kazakh ethnic culture and Kazakhstan realities in the linguistic consciousness of the representatives of American ethnolinguoculture.

To obtain reliable research results, a sociocultural questionnaire survey was conducted. The questionnaires contained 
questions about Kazakhstan, Kazakhstan realities and traditional values of the Kazakh people. The written answer to these questions included comments, reflections, and personal attitude of the respondents towards Kazakhstan and the Kazakhs, which allowed us to describe and consider the problems of intercultural interaction fully. The names of the respondents were changed.

Besides, corpus-based methods of language learning based on the use of new information technologies, a statistical approach, and a method of computer data processing have also been used.

\section{Literature Review}

The theoretical and methodological research base includes the ideas of linguistic consciousness developed under the activity theory by A.N. Leontiev, the ethnos theory by L.N. Gumilev, and the concept of culture by E.S. Markaryan. Besides, taking into account the fact that the results of the experimental data contain axiological characteristics, in the study we draw attention to the classification of cultures by Fons Trompenaars, which is based on value orientations. "Culture is the values and norms that people hold to be more effective in surviving in a hostile natural environment... culture is about meaning, about what meaning is given to things, action and behaviour" (Trompenaars, \& Woolianis, 2003: 57). He created an original model of crosscultural measurement of values and distinguished the following cultural differences represented by pairs of contrasting concepts: universalism - particularism (universality separation); individualism-collectivism; achievement - origin (ascription); affectivity (emotionality) - neutrality; specificity diffuseness (peculiarity - anonymity).

Intercultural interaction implies the knowledge of ethnocultural stereotypes, a phenomenon of which is considered in the works of linguists, sociologists, ethnographers, knowledge engineers, psychologists, and ethnopsychologists (Apresyan, 2006: 232; Sorokin 1994: 56).The knowledge of stereotypes - specific "reduced models" of behaviour - can facilitate communication, acting as signals of various situations and meanings. In intercultural communication, the role of stereotypes of behaviour (including those of speech behaviour) increases. Intercultural communication is "a case of the functioning of consciousness in abnormal ("pathological") conditions when there is no optimal community of consciousness of communicants. Other culture is perceived as a "deviation from standard"; at the same time, the images of one's own culture are naturally regarded as a standard and other culture is comprehended by bringing consciousness images of the other culture to the images of one's own culture" (Tarasov, 1996: 18). In this regard, there is a reason to believe that the main reason for misunderstanding in intercultural communication should be seen in the inconsistency of the national consciousness of communicants. According to E.F. Tarasov, an image of linguistic consciousness integrates mental knowledge formed by the subject mainly in verbal communication and sensory expertise arising in consciousness as a result of processing of perceptual data received from sense organs in substantive work (Tarasov, 2003: 3).

During the stay in Kazakhstan under conditions of direct intercultural interaction, the Americans developed certain impressions and ideas about the modern Kazakhstan realities and heterostereotypes about Kazakhs, the perception and evaluation of which we tried to identify and analyse by studying the language consciousness. For this purpose, a freeassociative experiment was conducted, the results of which are presented in the next part of the study.

\section{Results}

As a rule, intercultural communication participants are considered, first of all, as representatives of various ethnic communities (Kiynova, Sansyzbayeva \& Akhmetzhanova, 2017: 142). Therefore, the study of problems of intercultural communication implies experimenting aimed at revealing the ethnocultural specificity of linguistic 
consciousness in associative "behaviour" of representatives of different ethnolinguocultures. The results of the associative experiment and the sociocultural questionnaire survey aimed at the generalisation and analysis of cultural associations made it possible to identify and describe: a) the totality of associates ranked by their frequency, as well as their semantic volume; b) axiological characteristics on each stimulus word. The processing of the experimental results is aimed at analysing cultural associations linked to Kazakhstan's realities in the consciousness of contemporary American youth. After the quantitative ranking of all associates, the most frequent lexical units-reactions forming the semantic field of a stimulus word were found.

1. The semantic field of a stimulus word "Kazakhstan" included such units as steppe, Nazarbayev, yurt, nomads, horses, blue flag, space, sky, guest (probably meaning "hospitable"), golden eagle, kurt, beshbarmak, horsemeat, Almaty, Astana, large country, postUSSR, oil, uranium, gold, yurt, the Russian language, unique soul, smile. Besides, very few associative reactions, colour-names, have been found (dark blue, light blue) and this is connected with the image of Kazakhstan and its symbols, namely, with the colour of the flag of the country. It follows that dominant associates were as follows: steppe, Nazarbayev, nomads, oil. These reactions are traditional and objective characteristics related to naturalclimatic, territorial, political, historical-cultural and socio-economic factors. In the authors' opinion, personal and evaluation characteristics are contained in unusual reactions, based on various frame structures. For example, an association of the "image" of Kazakhstan with a famous boxer Gennady Golovkin, who won worldwide fame and became a Kazakh national hero, has a cross-cultural significance. The abbreviation GGG became a metaphor of the proper name as a cultural-symbolic code.

The semantic volume of a stimulus word "the Kazakhs" consisted of the reactions, the most frequent among which were descriptive units characterising the ethnic characteristics of the
Kazakhs: hospitable, kind, calm, swarthy, Asians, nomads. The most frequent associates can be referredtoethnodescriptors, which are understood as adjective language units serving to describe the ethnic character. "Ethnodescriptors adjectivise the main value orientations that determine the mentality of representatives of a certain ethnolinguoculture; therefore, their comparability represents some difficulties. It is not easy (if not impossible) to select the English language analogues of Russian adjectives used to describe the character: long-suffering, conscientious, humble, reckless, merciful, badtempered, sensitive, spontaneous, etc. In turn, the Russian language capabilities will be limited about such the English language descriptors as creative, supportive, helpful, friendly, easygoing, positive, efficient, fun-loving, etc. In this case, this is not about the compatibility of linguistic units from different semiotic systems, but about the comparability of images with peculiar axiological content" (Privalova, 2005: 321).

The processing of questionnaire data shows that an adjective hospitable is the most popular ethnodescriptor. Hospitality as a traditional value and a basic cultural concept characterising the ethnos is found almost in each questionnaire, while this associate is the first and the main in the semantic field of a stimulus word "the Kazakhs". Indeed, the Kazakhs believe that a guest is a messenger of God and he/she brings prosperity and wealth to the house; a guest should be met and seen off with great honour, wined and dined with the most delicious food (Lichman \& Doroshenko, 2016: 229).

It is no coincidence that in the Kazakh language, there is a large number of proverbs and sayings containing the people's wisdom, which teaches to respect and entertain the guests. For example, "қонағыңның алтынын алма, алғысын ал" (lit.: let your guest leave you not his gold, but his gratitude); "асына тойғызбасан да, ақ ниетіне тойғыз" (lit.: if you cannot feed the [guest] with food, then at least show him your sincere intention), etc. 
While planning their studies in Kazakhstan, American students received specific background knowledge of national-cultural values. However, they felt real hospitality already here, living in Kazakh families. Thisis confirmed by the results of the questionnaire survey, which contain lengthy comments and personal attitude of respondents to the issue. For example, the following unambiguous answers were given to the questions "What features of the national character (mentality, lifestyle) can you name?" and "What impressed you most (surprised, amazed) during your stay in Kazakhstan?": "Hospitality and openness of the Kazakh culture made a delightful impression on me. In Russia the splendour of big cities was impressive" (from Pitt'squestionnaire); "The hospitality and warmth of the Kazakh culture surprised me. Of course, inefficiency in society as a remnant of the Soviet time always surprises" (from Kate's questionnaire); "We are guests. This means that people do everything possible to explain to us their culture and history" (from Hall's questionnaire).

The results of the associative experiment and the sociocultural survey show that numerous associations and keywords in the answers to questions contain the essential assessments that generalise the ethnic "portrait" of the Kazakhs.

Less frequently used and unusual reactions are as follows: Russian-speaking, outspoken, patient, old-fashioned, lazy sometimes, Muslims, few, dombra, yurt, meat, well-fed, smile, Genghis Khan, GGG. The analysis of these reactions allows making a conclusion that they are semantically heterogeneous: along with the names of ethnocultural Kazakh realities (yurt, light blue flag, steppe, beshbarmak, kurt) and descriptive adjectives for describing human personality and character (hospitable, kind, calm, swarthy, straightforward, patient, etc.) there are precedent phenomena, attributes and cultural symbols: anthroponyms (Nazarbayev, GGG - Gennady Golovkin, Genghis Khan), toponyms (Almaty, Astana).

In the authors' opinion, associates lack colour images, except for the adjective light blue, which symbolises the primary attribute of the country - its flag. The uniqueness of colouremes is that in their semantics there is a complex of social knowledge expressed in comparisons, toponyms and anthroponyms. We expected colour-denoting reactions to stimulus words indicating the main Kazakhstan cities - Astana and Almaty, which are associated with different colour perceptions. Cultural symbols associated with colour images are significant for specific ethnos since they reflect collective representations of an object and its properties.

\section{Discussion}

The processing of questionnaire data allows making the following conclusion: if a word has both objective and subjective semantics, this allows structuring associative systems existing in different ethnolinguocultures. For example, ambiguous assessment characteristics were obtained for reaction words associated with the images of a Kazakh man and a Kazakh woman. They reflect not only gender differences, but also express different axiological characteristics. The most frequent associates by their degree of the opposition are given in Table 1. 
Table 1: Syntagmatic Associative Parallels Revealed as Reactions to Stimuli- "A Kazakh Man"

"A Kazakh Woman."

A Kazakh Man

Soviet, Asian, unfashionable, strong, tall, short

respects parents, hard-working

friendly, easy-going, calm, reticent, jeans, blue suit
A Kazakh Woman

beautiful, fashionable, Asian, long hair, swarthy, tall, muscular, weak appreciates her family, wants to be married, obedient (meaning "to be subordinate"),

hardworking, emotional, strong and weak at the same time, attractive, shy, clothes, makeup

sexist, lazy, aggressive, stubborn, irresponsible, not caring, inconsiderate, lacks confidence, rude sometimes, strong-willed, emotional, usually kind, heavily made up, pregnant, tired, loud does not clean up after himself, cigarettes

\section{Source: Results of the Study Conducted by the Authors}

As seen from Table 1, most reactions are oneword and stereotyped with a predominance of socio-indicative characteristics. At the same time, the qualities of a Kazakh woman as an Eastern woman, a preserver of the hearth and family values are regarded as positive. American respondents appreciate her appearance: beautiful, fashionable, Asian, long hair, swarthy, tall, strong, weak. Such assessment adjectives have a generalised characteristic. In the authors' opinion, the "image" of a Kazakh woman consists of mainly positive moral qualities reflected in the resulting associates: hard-working, emotional, strong and weak at the same time, interesting, shy, appreciates her family, wants to be married. Indeed, since the beginning of time, the Kazakhs treated their daughters reverently, paid special attention to their upbringing, taught them good manners, the mother made every effort to ensure that her daughter would become a good housewife in the future. Such moral qualities as respect for elders, reverence for family traditions, modesty, obedience, reticence, industriousness, patience are the fundamental national-traditional values (Galiev, 2016: 58)

At the same time, there are few unexpected associative reactions like pregnant, tired, which also attract our attention. In the authors' opinion, these associates are connected with the socio-economic realities of modern Kazakhstan society. In recent years, a high birth rate has been observed in Kazakhstan, the so- called baby boom. Therefore, pregnant women are quite often seen in the streets of Almaty, a vast metropolis of the country. In general, the similarity of associative reactions demonstrates the identity of the images in the minds of the participants of the experiment.

The content of associative reactions illustrates the following positive qualities of a Kazakh man: respects parents, hard-working, friendly, easy-going, calm, and reticent. At the same time, the contrastive analysis of associative parallels based on gender shows that the respondents included a large number of negatively labeled associates in the syntagmatic series of a stimulus word "a Kazakh man": sexist, lazy, aggressive, stubborn, irresponsible, not caring, inconsiderate, lacks confident, rude sometimes, does not clean up after himself, cigarettes. The generation of such associative reactions in the linguistic consciousness of American respondents can be regarded as "collision" or interaction of two axiological systems. This is because an ethnolinguistic personality with his/her value system, prejudices and outlook on life is at the centre of the process of intercultural communication. At the same time, personality development depends on sociocultural realities and family values, under which the worldview of a person was formed. For example, representatives of American ethnolinguoculture do not accept the infringement of women's rights in a modern democratic society. Therefore, an associate "sexist" is one of the frequent responses; it 
shows a critical attitude to this social phenomenon. Indeed, traditionally in the Kazakh family, there is the conviction that housework and children upbringing are the responsibility of women. (Aljanova, Borbassova \& Rysbekova, 2016: 34).

American respondents answered the question: "What is your opinion on the role of women and men in Kazakhstan? Compare it with gender relations in your country" as follows: "Rights of women in Kazakhstan are much less than in America. I mean concerning work, education, politics and family life. The concept of traditional roles for women and men still exists in Kazakhstan" (from Conrad's questionnaire); "In the USA women have the same rights as men (there are exceptions: for example, "hidden sexism", which is manifested, for example, in differences in wages). Women also hold public posts. A woman can become the next US president. In Kazakhstan, women do not have all the rights, in comparison with the West. It seems that the state thinks that the primary goal of mothers should be to give birth to children" (from William's questionnaire); "In the USA the role of the wife is not very different from the role of the husband. We think of the role of "parents" in general and not of the role of mom or dad. In Kazakhstan, women do the housework and cook every day. But in Kazakhstan, there is a revival of Islam, and I am afraid that it will divide women and men even further" (from Amanda's questionnaire). These comments contrast the role of women in a modern democratic society and confirm the thesis that gender discrimination is a social problem that causes many arguments and contradictions (Nusupzhanovna \& Sailaubekkyzy, 2017: 744).

In the authors' opinion, the associative reaction lazy with male representatives is connected with the ideology of sexism. It is no coincidence that associates sexist and lazy were frequent in the description of a Kazakh man. Laziness as weakness, which deserves blame, is inherent in the Kazakhs in general. This was also written by a great Kazakh poet and enlightener Abai in his philosophical book "The Words of Edification".
As a national prophet, he earnestly writes about unacceptable qualities of a person, such as laziness, idleness, ignorance, about the importance of work and enlightenment in a person's life. Folk wisdom in Kazakh proverbs and sayings condemns laziness as a serious vice and encourages people to respect work (Alimzhanova, Aldambergenova, Mantayeva, \& Gabitov, 2015: 585).

Compare: "Ақымақ күлкіге тоймайды, жалқау ұйқыға тоймайды" (lit.: A stupid person cannot be sated with laughter and a lazy person - with sleep) "Еңбексіз - өмір тұл, ойсыз - көңіл тұл" (lit.: Life is empty without labour, there are no feelings without thoughts). In American culture, labour as a basic value is an integral part of success and prosperity. Hard working achieves American success: "When there is a will, there is a way".

Thus, the comparison of syntagmatic associative parallels revealed as reactions to stimulus words "a Kazakh man" - "a Kazakh woman" allows determining the value-appraisal representation of American informants about the sociocultural determinism of gender relations in Kazakhstan society and traditional family values.

The most exciting and unexpected results are presented in a cluster of words with nationalcultural Kazakh realities - lexical units that are one-sidedly lacunised for representatives of American ethnolinguoculture: nauryz, beshbarmak, bauyrsaki, kumys, tenge. Associative reactions to these stimulus words are diverse and subjective. For example, as for stimulus words, beshbarmak and bauyrsaki denoting Kazakh national dishes, in the associative field appear the reactions about their taste qualities, and then - about the ingredients of these dishes. The most frequent associates delicious, fatty are the reactions to the word bauyrsaki which are dough balls fried in oil. As a rule, associates-attributes related to the image of an object or phenomenon are nation-specific: holiday, apashka (diminutive to the word "apa" - a grandmother), nauryz (a day of spring equinox which is a national holiday of Turkic-speaking peoples), guests (dastarkhan is 
laid for the guests; it is a festive table with a necessary attribute - bauyrsaki). In questionnaires, respondents note the following associations: meat from which beshbarmak is cooked and how it is eaten - horse meat (in the traditional Kazakh cuisine the most delicious beshbarmak is made from horse meat); fingers (this dish is traditionally eaten by hands, for this reason, the word beshbarmak is literally translated as "five fingers").

The associative response to a stimulus word tenge, national currency of the Republic of Kazakhstan, is, on the one hand, due to its aesthetic appeal and colorful design of banknotes with national-cultural symbols: nice banknotes, more colours, art, more delicate than dollar banknotes; on the other hand, due to the socio-economic situation in the Republic of Kazakhstan during the stay of American students, in particular, due to an increase in inflation processes and this prevails in the reactions: falling tenge, dollar rate, inflation, weak, depreciated money, unstable, economy. The obtained results indicate that subjective semantics generates non-standard associative structures of the image of the world in linguistic consciousness.

\section{Conclusion}

In the article, based on experimental data, the axiological characteristics of the realities of modern Kazakhstan society and the ethnic character in the perception of representatives of American ethnolinguoculturewere described. All received associations are ranked by the degree of frequency, which makes it possible to construct the associative field of the ethnos and reveal its uniqueness. When analysing the answers of informants, common reactions related to the construction of syntagmatic and paradigmatic models of stimulus words were identified.

The results of associative reactions illustrate that ethnocultural specificity often leads not to interaction, but to "collision" of worldviews of communicants. Therefore, in the process of intercultural communication, the divergence of the two opposite axiological systems in terms of national mentality, centuries-long way of life and sociocultural attitudes can be overcome by axiological adaptation, that is, by making historical-cultural comments: for example, the nomadic way of life resulting in the profound philosophical worldview, the patriarchal form of the Kazakh family preserved until the beginning of the 20th century, the existence of the institution of polygamy in the Kazakh traditional society, etc.

The obtained experimental data make it possible to conclude that associative reactions are predominantly positive and neutral. A critical attitude toward social problems, in particular, to existing gender stereotypes, is observed in the associative tactics of Americans.

In general, the obtained associates testify to the national-cultural markedness of linguistic sign and allow constructing the conceptual structure of the image of Kazakhstan and its realities in the consciousness of the linguistic personality of another culture.

\section{References}

Akpinar, N.-J., Alfano, S., \& Kersten, G. (2017). The role of sentiment and cultural differences in the communication process of e-negotiations. Lecture Notes in Business Information Processing, 293, 132-144.

Alimzhanova, A. S., Aldambergenova, G. T., Mantayeva, T. S., \& Gabitov, T. H. (2015). Kazakhstan: The choice of civilizational priorities. Mediterranean Journal of Social Sciences, 6(5S1), 582-588.

Aljanova, N., Bobassova, K., \& Rysbekova, S. (2016). A semiotic analysis of the yurt, clothing, and food eating habits in Kazakh traditional cultures. International Journal of Critical Cultural Studies, 14(1), 27-36.

Apresyan, Yu. D. (2006). Yazykovaya kartinamiraisistemnayaleksikografiya [The language picture of the world and systemic lexicography]. Moscow: Yazyki slavyanskih kultur, 912.

Drotianko, L., \&Yahodzinskyi, S. (2016). Information environment as the intercultural communication space. MATEC 
Web of Conferences, 106, 01006. DOI: 10.1051/matecconf/20171060100 SPbWOSCE-2016 6

Fiedler, E., Jansen, R., \& Norman-Risch, M. (2004). America in Close-up. Harlow, UK: Longman Group UK Ltd.

Galiev, A. (2016). Mythologization of history and the invention of tradition in Kazakhstan. Oriente Moderno, 96(1), 4663.

Kiynova, Zh. K., Sansyzbayeva, S. K., \& Akhmetzhanova, A. I. (2017). Axiological characteristics of ethnocultural realities in cross-cultural communication. Voprosy Kognitivnoy Lingvistiki, 3,142-147.

Karasik, V. I. (2002). Yazykovoi krug: Lichnost, kontsepty, diskurs [The language circle: Personality, concepts, discourse]. Volgograd, Russia: Peremena.

Kecskes, I. (2017). Context-dependency and impoliteness in intercultural communication. Journal of Politeness Research, 13(1), 7-31.

Kim, Y. Y. (2014). Interpersonal communication. Interpersonal communication in intercultural encounters (pp. 517-540). UK: University of Oklahoma, pp. 517-540.

Kubryakova,

E.

S.

(2010). Lingvokulturologicheskij status dramy [Linguistic and cultural status of drama]. Voprosy kognitivnoj lingvistiki, 2, 64-73.

Lichman, Y. Y., \& Doroschenko, T. M. (2016). Traditions of art and craft decoration and architecture of Kazakh yurt as a source of modern art. European Journal of Science and Theology, 12(3), 221-232.

Nusupzhanovna, N. D., \& Sailaubekkyzy, A. (2017). The spiritual and moral values: Tradition and transformation. Man in India, 97(2), 753-762.

Privalova, I. V. (2005). Interkultura iverbalnyiznak

(lingvokognitivnyeosnovymezhkulturnoiko mmunikatsii): Monografiya [Interculture and Verbal Sign (Intercultural
Communication Linguocognitive Basics): Monograph]. Moscow, Russia: Gnosis.

Sorokin, Yu. A. (1994). Ehtnicheskaya konfliktologiya [Ethnic Conflictology]. Samara: Russkii litsey, 94.

Tarasov, E. F. (1996). Mezhkulturnoe obshchenie novayaontologiyaanalizayazykovogosoznan iya [Intercultural Communication - New Ontology of the Analysis of Linguistic Consciousness]. In N. V. Ufimtseva (Ed.), Etnokulturnaya spetsifikayazykovogosoznaniya

[Ethnocultural Specificity of Linguistic Consciousness] (pp. 7-22). Moscow, Russia.

Tarasov, E. F. (2003). Predislovie [Foreword]. In Yazykovoe soznanie: ustoyavsheesyaispornoe: tez. XIV mezhd. simpoziumapopsikholingvistikeiteoriikomm unikatsii, Moskva, 29-31 maya 2003 g. [Linguistic Consciousness: Traditional and Controversial: Theses of the XIVth International Symposium on Psycholinguistics and Communication Theory, Moscow, May 29-31, 2003] (p. 3). Moscow, Russia.

Trompenaars, F., \& Woolianis, B. (2003). Business Across Cultures. Capstone Publishing Ltd.

Ufimtseva, N. V. (2004). Predislovie [Foreword]. In N. V. Ufimtseva (Ed.), Yazykovoe soznanie: teoreticheskieiprikladnyeaspekty: Sb.st. [Linguistic Consciousness: Theoretical and Applied Aspects: Collection of Articles] (pp. 3-5). Barnaul, Russia: Publishing house of Altay University.

Vezhbitskaya, A. (2001). Ponimanie kultur cherez posredstvo klyuchevyh slov (Yazyk. Semiotika. kul'tura. Malaya seriya). Monografiya [Yazyki slavyanskoj kul'tury]. Moscow, 288.

Vorkachev, S. G. (2002). Koncept schast'ya v russkomyazykovomsoznanii: opytlingvokul'turologicheskogoanaliza [Concept of happiness in the Russian language consciousness: the experience of 
linguistic and cultural analysis]. Krasnodar, 142.

Wang, W., \& Zhou, M. (2016). Validation of the short form of the intercultural sensitivity scale (ISS-15). International Journal of Intercultural Relations, 55, 1-7. 